OPEN ACCESS

Edited by:

Virginia Lorenz,

National University of Littoral,

Argentina

Reviewed by:

Jun Yoshinaga,

Toyo University,

Japan

Laura Sterian Ward,

State University of Campinas,

Brazil

${ }^{*}$ Correspondence:

Renata Marino Romano romano@unicentro.br

Specialty section:

This article was submitted to

Translational Endocrinology,

a section of the journal

Frontiers in Endocrinology

Received: 08 November 2020

Accepted: 03 March 2021

Published: 19 March 2021

Citation:

Romano RM, Oliveira JM,

Oliveira VM, Oliveira IM,

Torres YR, Bargi-Souza $P$,

Martino Andrade AJ

and Romano MA (2021)

Could Glyphosate

and Glyphosate-Based

Herbicides Be Associated

With Increased Thyroid

Diseases Worldwide?

Front. Endocrinol. 12:627167.

doi: 10.3389/fendo.2021.627167

\section{Could Glyphosate and Glyphosate- Based Herbicides Be Associated With Increased Thyroid Diseases Worldwide?}

\author{
Renata Marino Romano ${ }^{1 *}$, Jeane Maria de Oliveira $^{1}$, Viviane Matoso de Oliveira ${ }^{2}$, \\ Isabela Medeiros de Oliveira ${ }^{3}$, Yohandra Reyes Torres ${ }^{4}$, Paula Bargi-Souza ${ }^{5}$, \\ Anderson Joel Martino Andrade ${ }^{6}$ and Marco Aurelio Romano ${ }^{1}$ \\ 1 Department of Medicine, State University of Central-West, Guarapuava, Brazil, 2 Instituto Federal do Paraná, Irati, Brazil, \\ ${ }^{3}$ Instituto para Pesquisa do Câncer, Guarapuava, Brazil, ${ }^{4}$ Department of Chemistry, State University of Central-West, \\ Guarapuava, Brazil, ${ }^{5}$ Department of Physiology and Biophysics, Institute of Biological Sciences, Federal University of Minas \\ Gerais, Belo Horizonte, Brazil, ${ }^{6}$ Department of Physiology, Federal University of Paraná (UFPR), Curitiba, Brazil
}

The increased incidence of thyroid diseases raises a series of questions about what the main predisposing factors are nowadays. If dietary restriction of iodine was once a major global health concern, today, the processes of industrialization of food and high exposure to a wide variety of environmental chemicals may be affecting, directly or indirectly, thyroid function. The homeostasis of hypothalamus-pituitary-thyroid (HPT) axis is finely regulated through the negative feedback mechanism exerted by thyroid hormones. Allostatic mechanisms are triggered to adjust the physiology of HPT axis in chronic conditions. Glyphosate and glyphosate-based herbicides are pesticides with controversial endocrine disrupting activities and only few studies have approached their effects on HPT axis and thyroid function. However, glyphosate has an electrophilic and nucleophilic zwitterion chemical structure that may affect the mechanisms involved in iodide oxidation and organification, as well as the oxidative phosphorylation in the ATP synthesis. Thus, in this review, we aimed to: (1) discuss the critical points in the regulation of HPT axis and thyroid hormones levels balance, which may be susceptible to the toxic action of glyphosate and glyphosate-based herbicides, correlating the molecular mechanisms involved in glyphosate toxicity described in the literature that may, directly or indirectly, be associated to the higher incidence of thyroid diseases; and (2) present the literature regarding glyphosate toxicity in HPT axis.

\footnotetext{
Keywords: thyroid diseases (source: MeSH NLM), glyphosate (N-[phosphonomethyl]glycine), glyphosate-based herbicides, thyroid gland-anatomy and histology, allostasis, reactive oxygen species, endocrinedisrupting chemicals
} 


\section{INTRODUCTION}

Thyroid diseases are the second leading cause of endocrine disorders (1). In iodine-sufficient regions, autoimmune thyroiditis is the main cause of thyroid dysfunction (2). The most common are Hashimoto's disease (also known as chronic autoimmune thyroiditis or autoimmune hypothyroidism) and Graves' disease (or autoimmune hyperthyroidism) $(3,4)$. Besides iodine deficiency or excess, genetic predisposition, selenium deficiency, infectious agents (such as Yersinia enterocolitica), and syndromic conditions such as Down syndrome and Turner syndrome are associated with autoimmune thyroiditis (2). The incidence of thyroid cancer is increasing worldwide. Age-standardized incidence rate from 1990 to 2013 showed an increase of $20 \%$. In some high-income countries, the increase is partially attributed to better screening programs. However, the causes may be considered multifactorial with geographic influences, iodine supplementation, environmental factors, such as endocrine disruptors and carcinogens (5).

Glyphosate is a very effective, non-selective and postemergent herbicide used to control harmful weeds for several crops $(6,7)$. It represents about $65 \%$ of the total herbicides used in Brazil (8). Glyphosate has been detected in urine samples of individuals occupationally, para-occupationally, or environmentally exposed to the herbicide, in urban and rural areas (9), raising the concerns of the toxic effects in children, pregnant women, basically in all age groups. Glyphosate has been associated with several diseases, including thyroid disorders (10). The increase in the use of glyphosate along the years presents a positive correlation with the increase in the prevalence of several intestinal diseases, such as celiac disease (10). Celiac disease and thyroid disorders prevalently coexist (11) and it is speculated that there is a possible link between exposure to glyphosate and the

\footnotetext{
Abbreviation: 2,4-D, 2,4-dichlorophenoxyacetic acid; AA, acrylamide; ATSDR, Agency for Toxic Substances and Disease Registry; BPA, bisphenol A; DEHP, di(2-ethylhexyl) phthalate; DIO1, deiodinase 1; DIO2, deiodinase 2; DIO3, deiodinase 3; DUOX1, dual oxidase 1; DUOX2, dual oxidase 2; DUOXA1, dual oxidase maturation factor 1; DUOXA2, dual oxidase maturation factor 2; EFSA, European Food Safety Authority; GBH, glyphosate-based herbicides; GPX3, Glutathione peroxidase 3; GS, Gosner stages; GSR, glutathione-disulfide reductase; GSTK1, glutathione S-transferase kappa 1; GSTP1, glutathione-Stransferase pi 1; $\mathrm{H} 2 \mathrm{O} 2$, hydrogen peroxide; HPT, hypothalamus-pituitarythyroid axis; IARC, International Agency for Research on Cancer; LOAEL, lowest-observed-adverse-effect level; L-VDCC, voltage-dependent calcium channels; MCT8, Monocarboxylate Transporters 8; MCT10, Monocarboxylate Transporters 10; NIS, sodium-iodide symporter; NTIS, non-thyroidal illness syndrome; OATP1C1, Solute Carrier Organic Anion Transporter family member 1C1; PAH, polycyclic aromatic hydrocarbons; PBDE, Polybrominated diphenyl ethers; PFOA, perfluorooctanoate; PFOS, perfluorooctane sulfonate; POEA, polyoxyethyleneamine; PRDX1, peroxiredoxin 1; PRDX3, peroxiredoxin 3; PRDX5, peroxiredoxin 5; PRL, Prolactin; PVN, hypothalamic paraventricular nucleus; RGD, arginyl-glycyl-aspartic acid domain; ROS, reactive oxygen species; rT3, reverse T3; SOD1, superoxide dismutase 1; T4, 3,5,3',5'-tetraiodothyronine or thyroxine; TACITUS, thyroid allostasis in critical illnesses, tumors, uremia, and starvation; TBG, Thyroid hormones binding proteins; Te, 3,5,3'-triiodothyronine or triiodothyronine; TH, thyroid hormones; THRA, Thyroid Hormone Receptors Alpha; THRB, Thyroid Hormone Receptors Beta; TPO, thyroperoxidase; TRE, thyroid hormone-responsive element; TRH, Thyrotrophin-Releasing Hormone; TRH-R, TRH receptor; TSH, Thyroid-Stimulating hormone; TSH-R, TSH receptor; TXN, thioredoxin; TXNRD1, thioredoxin reductases 1
}

development of these pathologies (10). Recently, glyphosate was associated with an increased risk for thyroid diseases in farmers $(12,13)$. However, the regulatory agencies did not find any evidence to classify glyphosate as an endocrine-disrupting chemical or a carcinogenic agent $(7,14)$. Despite this, there are evidences between glyphosate exposure and incidence of NonHodgkin lymphoma (15-17) and the International Agency for Research on Cancer (IARC/WHO) classified it as "probably carcinogenic to humans" (Group 2A) (9, 18-22). This discrepancy is possibly due to the evaluation of glyphosate alone by EFSA and ATSDR, not considering the chemical agents contained in lesser amounts in commercial formulations.

In this context, the objectives of this review are discuss the critical points in the regulation of HPT axis and thyroid hormones levels balance, which may be susceptible to the toxic action of glyphosate and glyphosate-based herbicides, correlating the molecular mechanisms involved in glyphosate toxicity described in the literature that may, directly or indirectly, be associated to the higher incidence of thyroid diseases.

\section{THE MAINTENANCE OF HYPOTHALAMUS-PITUITARY-THYROID AXIS HOMEOSTASIS AND ITS ALLOSTASIS-ADAPTIVE RESPONSES}

\section{Physiology of the Hypothalamic-Pituitary- Thyroid Axis}

The neuroendocrine system, which comprises the hypothalamuspituitary-gland axis, is responsible for the homeostatic regulation of most physiological processes such as reproduction, growth, metabolism, energy balance and response to stress. In particular, the HPT axis controls the thyroid gland metabolism and synthesis and the secretion of thyroid hormones (THs) (Figure 1). The neurons from hypothalamic paraventricular nucleus (PVN) secrete the tripeptide Thyrotrophin-Releasing Hormone (TRH) in the hypothalamic-pituitary portal system, reaching the anterior pituitary gland. The TRH interacts with its receptor (TRH-R) located on plasma membrane of thyrotrophs and lactotrophs and stimulates Prolactin (PRL) and Thyroid-Stimulating hormone (TSH) biosynthesis and secretion $(23,24)$. After being released into the bloodstream, the TSH reaches its receptor (TSH-R) in the basolateral plasma membrane of thyroid follicular cells and stimulates the thyroid gland metabolism and several stages involved in the biosynthesis and secretion of THs $(25,26)$. In humans, the thyroid gland synthesizes and secretes about $75 \%$ of $3,5,3^{\prime}, 5^{\prime}$-tetraiodothyronine (T4 or thyroxine) and $25 \%$ of $3,5,3^{\prime}$ triiodothyronine (T3) under regulation of hypothalamus and pituitary gland $(27,28)$.

Once it is in the bloodstream, the highest percentage of THs (about $95-99 \%$ ) is carried by specific binding proteins such as Thyroid hormones binding proteins (TBGs) and Transthyretin or by albumin in dynamic equilibrium with the free fraction (about only 1-5\%). The free fraction is responsible for the actions in the target tissues, which include virtually all cells. The proper 


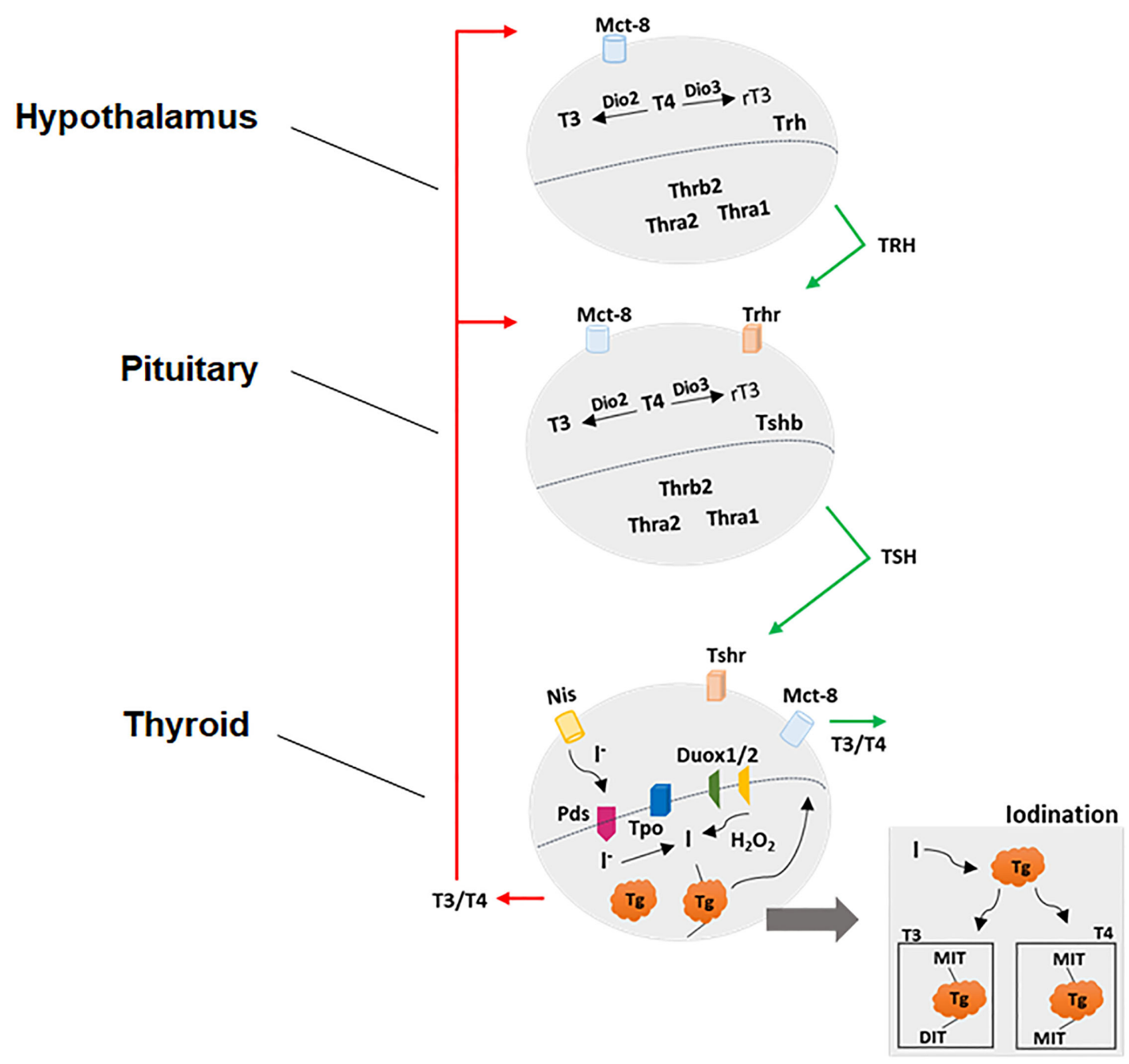

FIGURE 1 | Physiological control of hypothalamic-pituitary-thyroid axis. See the text for detailed explanations.

functioning of the molecular mechanisms involved in actions of THs, including the regulation of HPT axis by negative feedback, depends on several cellular components as specific transporters and signals mediated by enzymes and receptors. Firstly, the transport of THs through the plasma membrane is mediated by the Monocarboxylate Transporters 8 and 10 (MCT8 and MCT10) and by Solute Carrier Organic Anion Transporter family member 1C1 (OATP1C1), however; only MCT8 has been identified as being specific to transport THs (29-31). Secondly, the most abundant product of thyroid is the T4, while about $90 \%$ of $\mathrm{T} 3$ in bloodstream is a product of intracellular conversion of $\mathrm{T} 4$ to $\mathrm{T} 3$ by a family of selenocysteine-containing enzymes in peripheral tissues. These enzymes are named as 5'-deiodinases and catalyze the removal of one iodine from the thyroid products generating intermediate thyroid products, which in turn exert a wide range of genomic and non-genomic actions in several tissues (32). Thirdly, the transcriptional or genomic actions of THs are mainly mediated by Thyroid Hormone Receptors Alpha (THRA) and Beta (THRB); transcription factors that belong to the nuclear receptor superfamily and modulate the transcriptional rate of target genes. THRs are encoded by two different genes, Thra and Thrb, however, several isoforms are generated by alternative splicing (33). The THRs exhibit higher affinity with T3 (compared to T4 and other THs such as T2 and reverse T3rT3) and are associated with specific sequences in DNA called thyroid hormone-responsive elements (TREs), located in the regulatory regions of a wide variety of target genes. Briefly, the THR-T3 interaction results in the recruitment of several coactivating proteins and positive modulation of the transcription of target genes (34). Finally, non-genomic actions triggered by THs were described taking place in the plasma membrane in association with the arginyl-glycyl-aspartic acid domain (RGD) present in $\alpha \mathrm{V} \beta 3$ integrin, in binding sites of rough endoplasmic 
reticulum (RER) and mitochondria, as well as through the association of THRs with specific enzymes in cytosol, such as PI3K. Among others, these actions include the modulation of glucose uptake and ions transport through the plasma membrane, alterations in cytoskeleton dynamics, kinase activities and transcripts stability (35).

\section{The Allostasis-Adaptive Responses of HPT Axis}

The HPT axis feedback control is a dynamic process which exhibits an important adaptive response, basically ensured by two mechanisms: relaying and conversion. The control of TSH secretion by TRH and of T4 by TSH are examples of relaying. On the other hand, the central and peripheral T4 conversion to T3 by deiodinases and the transport of THs by plasma and OATP1C1 and MCT8 transporters exemplify the conversion mechanism (36). Thus, alterations in the activity or expression of deiodinases and thyroid hormones transporters are associated to the adaptive response observed in several stressful conditions in an attempt to maintain the required $\mathrm{TH}$ concentration in serum. In this sense, the DIO2 activity in tanycytes maintains constant in physiological conditions. During an infectious condition, however, an increase in DIO2 activity leads to higher levels of hypothalamic T3, which might be the molecular mechanism associated to the central hypothyroidism observed in the nonthyroidal illness syndrome (37).

These reactive regulations of HPT axis are characterized as thyroid allostasis-adaptive responses types 1 and 2 (38). The type 1 allostasis is usually characterized by a low or normal TSH level and free T4 levels, low total T4, T3 and free T3 serum concentrations and higher levels of rT3. It is mostly commonly observed in hospitalized patients presenting non-thyroidal illness syndrome (NTIS) or thyroid allostasis in critical illnesses, tumors, uremia, and starvation (TACITUS). In hospitalized patients, the NTIS or TACITUS is commonly observed (38). The type 2 allostasis is usually observed in psychosocial stress, pregnancy, obesity associated with metabolic syndrome, adaptation to cold and post-traumatic stress disease. In contrast to type 1 allostasis, the TSH and free T4 levels are high or normal, the free T3 and total T4 and T3 levels are high, while the levels of rT3 are low. These alterations are associated with increased levels of THs binding protein levels, upregulation of DIO1 and 2 activities and downregulation of DIO3.

Therefore, there are substantial differences regarding the molecular mechanisms involved in types 1 and 2 adaptive allostatic-responses of HPT axis. In general, they are the result of an HPT axis adaptation that is acutely essential to adjust the thyroid and body metabolism in critical illnesses and several stressful conditions. However, the exposure to chronic stressful conditions, drugs or endocrine disruptors can overcome the HPT axis adaptive capacity determined by the saturation of receptors and enzymes, leading to allostatic overload that may culminate in pathological thyroid disorders. Rats prepubertally exposed to acrylamide (AA) present several alterations in the HPT axis with higher levels of $\mathrm{THs}$ in serum. Interestingly, compensatory mechanisms were observed in TH-target tissues, such as an increase in Dio3 mRNA expression in the liver and a reduction in Mct8 transcript content in the hearts of AA-treated rats, suggesting an allostatic regulation (39). Similar mechanisms of allostatic regulation were evidenced in the HPT axis and targettissues of rats prepubertally exposed to silver nanoparticles (40).

Albeit the allostasis-adaptive responses of HPT axis are essential for the proper adjust to critical conditions, they difficult the clinical diagnosis of thyroid diseases, since the hormonal levels that comprise this axis exhibit a wide range of reference values. Furthermore, many patients are classified in the subclinical hypothyroidism or hyperthyroidism category and remain without treatment until the rise of these respective thyroid pathological conditions, hypothyroidism and hyperthyroidism (41).

Environmental stressors such as exposure to endocrinedisrupting chemicals that target the HPT axis may impose an additional allostatic burden (38). This is of particular concern during fetal and early postnatal life given the critical role THs exert on developmental processes, including body growth and neurodevelopment, and the lifelong consequences that may result from improper $\mathrm{TH}$ action on developing organisms, including cognitive deficits, impairment of psychomotor and language abilities, and other behavioral problems (42). Although thyroid hormone status during fetal life resembles a type 1 allostatic response with low circulating total and free T3, the levels of T3 in the brain are preserved due to an increased DIO2 activity (38). Thus, chemical exposures that alter the fine hormonal balance during this critical developmental stage may disrupt TH signaling and result in adverse neurodevelopmental outcomes.

\section{THYROID HORMONES SYNTHESIS PATHWAY AS A POSSIBLE TARGET TO TOXICANTS}

DUOX1 and DUOX2 are glycoprotein members of the NADPH oxidase family that generate hydrogen peroxide ( $\mathrm{H} 2 \mathrm{O} 2)$. These proteins form a heterodimer with the specific maturation factors DUOXA1 and DUOXA2, a necessary step for the maturation and activation of DUOX enzyme complexes. These proteins are co-localized with thyroperoxidase (TPO) in the apical membrane of thyrocyte and play a fundamental role in the synthesis of the thyroid hormones. TPO reduces the pairs of iodinated tyrosine in thyroglobulin in order to form thyroxine and triiodothyronine using hydrogen peroxide, heme beta and $\mathrm{Ca} 2+$ as cofactors $(43,44)$.

Glutathione peroxidase 3 (GPX3) catalyzes the reduction of $\mathrm{H} 2 \mathrm{O} 2$ and is highly abundant in the thyroid gland (45). Therefore, excess of $\mathrm{H} 2 \mathrm{O} 2$ and other reactive oxygen species (ROS) generated by DUOX system may be catalyzed by GPX3, protecting the cells against the oxidative damage. This is a finely regulated process between the balance among ROS generation and removal. Besides GPX3, thyrocytes express other members of the enzymatic antioxidant system, such as catalase, superoxide 
dismutases 1, 2 and 3 (with higher levels of SOD1), glutathionedisulfide reductase (GSR), several members of glutathione-Stransferase family (with higher levels of GSTP1 and GSTK1, respectively), several members of peroxiredoxin family (with higher levels of PRDX1, PRDX5 and PRDX3, respectively), thioredoxin (TXN) and thioredoxin reductases 1, 2 and 3 (with higher levels of TXNRD1) (45).

In thyroid dysfunctions, oxidative stress accompanied by thyroid epithelial cell inflammation is frequently observed. Both autoimmune thyroid diseases, Hashimoto's thyroiditis and Graves' disease present increased ROS production and decreased antioxidant activity (46). This imbalance was similarly observed in thyroid cancer cells; furthermore, these cells seem to reprogram their metabolic activity to survive in conditions of high oxidative stress and with a compromised antioxidant system (47).

The TH production, per se, is a high source of ROS in the thyrocyte. Nevertheless, we must include the oxidative phosphorylation by mitochondria in this equation. The mitochondrial respiratory chain consists of a series of reactions where electron transfer occurs. Initially, dehydrogenases collect electrons from the catabolic pathways and channel them to universal electron acceptors (NAD+, NADP+, FAD). The dehydrogenases linked to $\mathrm{NAD}+$ removes two hydrogen atoms from their substrates, one of which is transferred as a hydride ion $(\mathrm{H}-)$ and the other is released as a proton $(\mathrm{H}+)$. Reducing equivalents of $\mathrm{NADH}$ are passed through a series of $\mathrm{Fe}-\mathrm{S}$ centers to ubiquinone. The latter transfers electrons to cytochrome $\mathrm{b}$ and then to $\mathrm{c}$ (cytochrome oxidase), which accumulates electrons and then passes them to $\mathrm{O} 2$, reducing it to $\mathrm{H} 2 \mathrm{O}$. This process generates ROS that are inactivated by an enzymatic antioxidant complex (48). The metabolic homeostasis is maintained by balancing these steps according to the cellular need for ATP (49).

Therefore, it is possible to realize that the thyroid gland is very susceptible to changes in the balance between the generation and removal of ROS originated from both the synthesis of thyroid hormones and the oxidative phosphorylation. Several chemical compounds are associated with the disruption of the enzymatic antioxidant system $(50,51)$. In this context, our focus will be in glyphosate. Glyphosate is a phosphonomethyl derivative of the amino acid glycine. Glyphosate exists as a zwitterion in water (52) and is stable to hydrolysis at $\mathrm{pH} 5,7$, and 9 at 5 to $35^{\circ} \mathrm{C}(53)$ Zwitterions are polyelectrolytes that contain both positively and negatively charged groups, but the overall charge is neutral (54). Glyphosate comprises one basic secondary amino function and three ionizable acidic sites with dissociation constants $(\mathrm{pKa})=$ 2.0 (phosphonic group), 2.6 (carboxylic group), 5.6 (ionization of the second $\mathrm{O}-\mathrm{H}$ bond in phosphonic group) and 10.6 (protonate amine group) (Figure 2) (55-57). The amino, carboxylate and phosphonate groups in glyphosate coordinate strongly to metal ions (mainly transition metal) at near neutral $\mathrm{pH}$ where both the carboxylate and phosphonate will be deprotonated (58). Therefore, glyphosate can coordinate to metals as a unidentate and most frequently bidentate and tridentate ligand. Even tetradentate complexes are possible if both $\mathrm{O}-\mathrm{H}$ bonds in<smiles>O=C(O)CNCP(=O)(O)O</smiles>

Glyphosate<smiles>[CH2+][NH+](CC(=O)O)CP(=O)([O-])O</smiles>

$2<\mathrm{pH}<2.6$<smiles>[CH3+][NH+](CC(=O)[O-])CP(=O)([O-])[O-]</smiles>

$5.6<\mathrm{pH}<10.6$<smiles>O=C(O)C[NH+]([IH])CP(=O)(O)O</smiles>

$\mathrm{pH}<<2$<smiles>O=C([O-])C[NH+]CP(=O)([O-])O</smiles>

$2.6<\mathrm{pH}<5.6$<smiles>O=C([O-])CNCP(=O)([O-])[O-]</smiles>

$\mathrm{pH}>>10.6$

FIGURE 2 | Chemical structure of glyphosate and its ionic forms under different pH conditions. 
phosphonate are ionized. Many of these structures are reported to have extensive hydrogen bonding stabilizing interactions (59). Stable metallic complexes with divalent (Cu, Zn, Mn, Ni, Cd, Pb, $\mathrm{Ca}$ and $\mathrm{Mg}, \mathrm{Ni}$ ), trivalent $(\mathrm{Cr}, \mathrm{Fe}, \mathrm{Co}, \mathrm{Al})$, monovalent ions ( $\mathrm{Li}$, $\mathrm{Na}, \mathrm{Ag})$ as well ammonium have been prepared $(56,59)$. The ability to bind anions or cations is influenced by the $\mathrm{pH}$ of the solution. At a pH below 2.0 glyphosate has a net positive charge due to protonation of the amino group, which contributes to an electrostatic attraction of negative charge counterions. But as the $\mathrm{pH}$ rises, the number of negative charges raise due to phosphonate and carboxylate groups ionization (Figure 2) Between pH 2.0 and 5.6, the phosphate acid is deprotonated, resulting in a negative charge allowing the interaction with monovalent cations. Between pH 5.6 and 10.6, the carboxylic acid is also deprotonated, further increasing the negative charge and increasing the possibility to bind to divalent cations. Above $\mathrm{pH} 10.6$, all functional groups are deprotonated, and the negative charge is maximal, binding to trivalent cations. It is important to keep these different ionization forms of glyphosate depending on $\mathrm{pH}$ in mind because of their possible interaction with physiological process.

At gastric acid $\mathrm{pH}$, the zwitterionic structure of glyphosate binds to anions and it is possible to hypothesize that iodide (I-) may interact with the agrochemical. Iodine and iodate from nutrition will be reduced in the gastrointestinal tract to iodide to be absorbed in the small intestine by sodium-iodide symporter (NIS) (60). Iodide glyphosate may not be transported by NIS, increasing its fecal excretion, and reducing its serum levels. At neutral and basic $\mathrm{pH}$, the molecule develops a high capacity to form complexes with cations. Thus, from the $\mathrm{pH}$ of the stomach, intestine and internal environment, glyphosate may eventually chelate important elements such as iodide, calcium, magnesium, selenium, iron, zinc, etc., as observed for plants $(61,62)$. Glyphosate has a strong ability to form complexes with cationic macro and micronutrients in solution, affecting its absorption and the metabolism of the plants $(61,63)$.

Furthermore, glyphosate also uncouples oxidation from phosphorylation in the metabolic cycle by increasing the permeability of mitochondrial membrane to protons and $\mathrm{Ca} 2+$, disrupting the ATP synthesis (64). For example, in Sertoli cells, glyphosate induces oxidative stress with depletion of antioxidant defenses, culminating in necrotic cell death via Ca2+ dependent mechanism (opening voltage-dependent calcium channels (LVDCC) and endoplasmic reticulum receptors (such as IP3 and ryanodine) (65).

\section{GLYPHOSATE TOXICITY IN HPT AXIS}

The wide possibility of formulating pesticides containing glyphosate (glyphosate-based herbicides, GBH) gives a high complexity of toxicological analysis from an experimental point of view, but not regulatory. Because the registration of commercial products is based on the active compound, in this case only the glyphosate, with no tests that consider the combined effects of the commercial formulations proposed by the manufacturers. Thus, additive, synergistic or potentially toxic effects are not evaluated. Although GBH has been increasingly used since 1996, it was only in 2019 that the toxicological profile of glyphosate was published, with the release for public consultation of varied information that until then was not available (7).

There is greater toxicity in commercial glyphosate formulations than when using only glyphosate, indicating that the toxicity of the inert ingredients is greater than that of the active ingredient, and that their presence produces a greater toxic effect (66). Since human beings and the environment are exposed to $\mathrm{GBH}$, not only to glyphosate, studies based on the real pesticide formulation are extremely relevant for raising awareness among regulatory agencies regarding the release and inspection of the use of these compounds and monitoring the occurrence of diseases in the exposed population.

In this regard, the identification of residues of glyphosate in soil, water and urine samples of human beings living or not near to crop farms raises the concern of International Agency for Research on Cancer (IARC/WHO) to support scientific evidences for potential glyphosate carcinogenicity and classified it as "probably carcinogenic to humans" (Group 2A) (9, 18-21). There are evidences between glyphosate exposure and the incidence of Non-Hodgkin lymphoma (15-17). Nonetheless, regulatory evaluations performed by EFSA and the ATSDR concluded that glyphosate is not toxic for the endocrine system or carcinogenic for human $(7,14,67)$.

In a recent review, Agostini et al. (68) brought together studies related to the exposure of human cells to glyphosate showing that the effects can be different depending on the type of cell, including genotoxicity, hemolysis, apoptosis, abnormal antioxidant defense, growth abnormal cell, among others. Although endocrine changes are not as discussed as the other toxic effects, they are chronic diseases that produce deleterious effects throughout the individual's life and require permanent attention by the health care system (69).

It is known that some chemicals which alter the genes involved in the HPT axis homeostasis may be associated with an increased incidence of thyroid dysfunction, such as hypothyroidism, hyperthyroidism and cancer (69-72). Among these, halogenated phenols, tributyltin, polychlorinated biphenyls and surfactants act on the hypothalamus and pituitary, while perchlorate, nitrates, thiocyanates, parabens and pesticides act on the thyroid gland itself $(73,74)$. Several other chemicals, such as phthalates, bisphenol A (BPA), brominated and perfluorinated flame retardants (PBDEs), polycyclic aromatic hydrocarbons (PAHs), perfluorooctane sulfonate (PFOS) and perfluorooctanoate (PFOA) were also reported to affect HPT axis (74-77). Specifically, organochlorine pesticides, polychlorinated biphenyls, aluminum, mercury, and vanadium could lead to thyroid autoimmunity (78). BPA and di-(2-ethylhexyl) phthalate (DEHP) would be related to the occurrence of Hashimoto's thyroiditis and thyroid cancer (79). Increased risk of papillary thyroid carcinoma was also observed after the human exposure to polybrominated diphenyl ethers (80), flame retardants [BDE-209 and tris (2-chloro-ethyl) phosphate (TCEP)] (81) and cadmium (82). 
Despite the knowledge of the deleterious effects of various chemicals on the thyroid gland, data on glyphosate toxicity is still scarce. The first evidence of thyroid toxicity was observed in amphibians (83). They are considered environmental sentinels for human health due to their sensitivity to the action of thyroid hormones during metamorphosis, since this process depends on the action of these hormones (84-86). Tadpoles were exposed to $\mathrm{GBH}$ formulations containing or not polyoxyethyleneamine (POEA) surfactant, glyphosate or only POEA surfactant and changes in metamorphosis were observed in tadpoles exposed to GBH containing POEA surfactant and in the group exposed only to POEA, but not in the group treated with glyphosate and $\mathrm{GBH}$ without POEA. In conclusion, POEA is toxic for HPT axis, but not glyphosate (83). As mentioned, the regulatory agencies only evaluated the glyphosate, not its formulation. Therefore, this study was a strong scientific support for the safety of glyphosate for the endocrine system.

Nine years passed before the next study questioning the thyroid toxicity of glyphosate in amphibians was published (Table 1). Lanctot et al. (87) observed a decrease in Trhb expression in the brain of tadpoles treated with GBH. NavarroMartín et al. (88) observed an increase in Dio2 and Dio3 expression in the brain and a delay in metamorphosis of tadpoles treated with GBH. Thereafter, other studies reporting deleterious effects of glyphosate formulations in the metamorphosis were conducted (89-95).

It has been noticed that in recent years the concern about the toxicity of the commercial formulation of glyphosate has increased. From 2017, some studies in rats and mice suggest that GBH is toxic to the HPT axis (Table 2), reinforcing what had already been observed for amphibians. de Souza et al. (96) evaluated the regulation of TSH production in adult male offspring of Wistar rats perinatally exposed to GBH (5 or 50 $\mathrm{mg} / \mathrm{kg}$ ) during the period of hypothalamic sexual differentiation (gestational 18 to postnatal day 5). Decreased TSH serum was observed along with a reduction of deiodinases expression in the hypothalamus, increased expression of thyroid hormone receptors in the pituitary and liver, and a metabolic profile compatible with that observed in animals with hypothyroidism. Manservisi et al. (97) administered glyphosate or GBH at 1.75 $\mathrm{mg} / \mathrm{kg}$ bw/day in drinking water from gestational day 6 until 120 days old. Male and female offspring were sacrificed at PND73 (6 weeks) or PND125 (13 weeks) and an increase in serum TSH levels in males was observed after 6 weeks of treatment for glyphosate, and after 13 weeks for GBH. Hamdaoui et al. (98) evaluated oral exposure to $126 \mathrm{mg} / \mathrm{kg} \mathrm{GBH}$ during 60 days in female Wistar rats and investigated its action on bone tissue in correlation with the hormonal status of estrogen and thyroid gland. Histological and immunohistochemical analysis of the thyroid showed that after the exposure there was a relative increase in the appearance of follicles at rest with a consequent decrease in the number of active follicles, in addition to the appearance of macrophages, dilated follicles and flattened epithelium, with decreased volume of colloid. These findings correlate with a state of hypothyroidism. The study also showed that hormone levels of T3 and free T4 decreased in the treated animals, while TSH levels increased and estrogen levels decreased, leading to an osteoporosis condition. Adult female Kunming Mice exposed to $250 \mathrm{mg} / \mathrm{kg} \mathrm{GBH}$ during 7 days by gavage presented increased levels of serum TRH, with decreased TSH, T3 and T4. The gene expression of Dio 2 and Mct8 were decreased in the hypothalamus, while in the pituitary the expression of Dio2, Mct8 e Trhr were increased. In the thyroid, the expression of Nis, Tpo, Tg and Tshr were decreased. All levels of the HPT axis were deregulated (99).

In humans, three studies evaluated occupational exposure to pesticides and suggested that GBH might be involved in thyroid dysfunction (Table 3). Kongtip et al. (13) observed higher levels of TSH, FT3, T3, and T4 in conventional farmers compared to organic farmers, while glyphosate was the most used compound, followed by paraquat and 2,4-dichlorophenoxyacetic acid (2,4D). In Brazil, researchers evaluated the levels of T3, T4 and TSH in soy producers who used pesticides, including glyphosate, and found a significant decrease in TSH and an increase in T3 and T4 (100). Another study evaluated the association between the use of pesticides, including glyphosate, and the incidence of hypothyroidism in applicators over a period of 20 years and found that the risk of hypothyroidism was significantly increased due to contact with these substances (12). It is noteworthy that in these studies the evaluated population was not exclusively exposed to $\mathrm{GBH}$, and detectable levels of other pesticides were also found. This does not exclude the probable toxicity caused by $\mathrm{GBH}$, but also does not make it possible to attribute it only to him. This is a characteristic of studies involving human beings and makes their interpretation fragile. Thus, more studies are needed to reinforce this hypothesis of thyroid toxicity in humans and that regulatory actions can be applied to GBH.

It is also clear throughout this review that the toxicity of GBHs is significant and that there is a need to consider the other ingredients of the commercial formulation in toxicological evaluations. Surfactants, additives and other substances are used in different proportions to obtain the final commercial formulation. This would practically make it impossible to use the toxicology procedures by regulatory agencies as they are done today, because it would require an extremely high amount of laboratory animals and the other procedures associated with these analyzes. However, other methods should be encouraged, such as an initial screening of these mixtures by in vitro and in silico methodologies.

\section{FUTURE PERSPECTIVES}

Finally, in addition to the known mechanisms of regulation involving the hypothalamic-pituitary-thyroid axis widely presented in this review, recent studies indicate that the intestine has an important role in the control of thyroid function, forming the Thyroid-Gut-Axis. According to this proposal, the intestinal microbiota affects mechanisms related to the absorption of iodide, conversion of T4 to T3, and also participates in the modulation of the immune system $(11,101)$. This is corroborated by studies where gut microbiota dysbiosis was correlated to Hashimoto's thyroiditis (102-104), Graves' disease (104), thyroid cancer and thyroid nodules (105). In parallel in the field of toxicology, recent studies indicate that 
TABLE 1 | Summary of the thyroid toxic effects after glyphosate or glyphosate-based herbicides (GBH) exposure in amphibians.

\begin{tabular}{|c|c|c|c|c|c|c|c|}
\hline Chemical & $\begin{array}{l}\text { LOAEL for } \\
\text { the study }\end{array}$ & $\begin{array}{l}\text { Experimental } \\
\text { model }\end{array}$ & $\begin{array}{c}\text { Age at } \\
\text { beginning } \\
\text { of exposure }\end{array}$ & Exposure duration & Exposure route & Main results & Reference \\
\hline $\begin{array}{l}\text { GBH (containing or not } \\
\text { POEA), } \\
\text { Glyphosate, or } \\
\text { POEA surfactant }\end{array}$ & $6 \mathrm{mg} / \mathrm{L}$ & Tadpoles & $\begin{array}{l}\text { Gosner } \\
\text { stages (GS) } \\
20 \text { and } 25\end{array}$ & 24 and $96 \mathrm{~h}$ & Water (aquaria) & $\begin{array}{l}\text { In GBH containing } \\
\text { POEA and POEA: } \\
\uparrow \text { Tail damage } \\
\downarrow \text { Tail length } \\
\uparrow \text { expression Thrb in } \\
\text { tail }\end{array}$ & $\begin{array}{l}\text { Howe et al. } \\
\text { (83) }\end{array}$ \\
\hline $\begin{array}{l}\text { GBH (VisionMax, Monsanto } \\
\text { Co.) }\end{array}$ & $0.21 \mathrm{mg} / \mathrm{L}$ & Tadpoles & GS 25 & 41 days & Water (aquaria) & $\begin{array}{l}\uparrow \text { expression Dio2 } \\
\text { and Dio3 in brain } \\
\text { Delayed } \\
\text { metamorphosis }\end{array}$ & $\begin{array}{l}\text { Navarro- } \\
\text { Martín } \\
\text { et al. (88) }\end{array}$ \\
\hline $\begin{array}{l}\text { GBH (Roundup ULTRA } \\
\text { MAX }{ }^{\circledR} \text {, Monsanto Co.) } \\
\text { or technical-grade glyphosate }\end{array}$ & $\begin{array}{l}\text { GHB: } \\
0.0007 \mathrm{mg} / \mathrm{L} \\
\text { GLY: } \\
15 \mathrm{mg} / \mathrm{L}\end{array}$ & Tadpoles & $\begin{array}{l}\text { GS } 25 \text { and } \\
\quad 36\end{array}$ & $96 \mathrm{~h}$ & $\begin{array}{l}\text { Water } \\
\text { (aquaria) }\end{array}$ & $\begin{array}{l}\text { GBH } \\
\text { Swimming activity } \\
\text { was affected } \\
\text { Effects on growth, } \\
\text { development, and } \\
\text { abnormalities } \\
\text { GLY } \\
\text { Effects on growth, } \\
\text { development, and } \\
\text { abnormalities }\end{array}$ & $\begin{array}{l}\text { Bach et al. } \\
(90)\end{array}$ \\
\hline $\begin{array}{l}\text { GBH (Roundup Original }{ }^{\circledR}, \\
\text { Monsanto) }\end{array}$ & $18 \mu \mathrm{gl}^{-1}$ & Tadpoles & GS 25 & 7 days & Water (aquaria) & $\begin{array}{l}\downarrow \text { Glycogen } \\
\uparrow \text { Total lipid levels } \\
\downarrow \text { Triglyceride levels } \\
\uparrow \text { Cholesterol levels } \\
\downarrow \text { Total protein } \\
\uparrow \text { LPO } \\
\downarrow \text { Glycogen, } \\
\text { cholesterol, total } \\
\text { protein and } \\
\text { triglyceride levels in } \\
\text { the liver } \\
\downarrow \text { Glycogen, Total } \\
\text { lipid, Triglyceride in } \\
\text { the tissue muscle } \\
\uparrow \text { Total protein in the } \\
\text { muscle } \\
\uparrow \text { Lipid peroxidation } \\
\text { levels in the Gills, } \\
\text { liver and tissue } \\
\text { muscle } \\
\uparrow \text { Weight and size }\end{array}$ & $\begin{array}{l}\text { Dornelles } \\
\text { and } \\
\text { Oliveira } \\
\text { (91) }\end{array}$ \\
\hline $\begin{array}{l}\text { GBH (Glyphogan }{ }^{\circledR} \text { Classic, } \\
\text { Monsanto Co.) }\end{array}$ & 2 mg a.e/L & Tadpoles & GS 25 & $\begin{array}{l}\text { 1st, 2nd, 3rd, 4th, or } \\
5 \text { th period of their larval } \\
\text { development, each } \\
\text { period lasting } 9 \text { days. } \\
\text { Or even throughout the } \\
\text { experiment period (5th } \\
\text { period larval) }\end{array}$ & Water (aquaria) & $\begin{array}{l}\downarrow \text { Body mass at } \\
\text { metamorphosis } \\
\text { during the entire } \\
\text { experiment } \\
\uparrow \text { Time to } \\
\text { metamorphosis } \\
\text { during the entire } \\
\text { experiment } \\
\text { Slow development of } \\
\text { tadpoles exposed } \\
\text { throughout the }\end{array}$ & $\begin{array}{l}\text { Mikó et al. } \\
\text { (92) }\end{array}$ \\
\hline
\end{tabular}


TABLE 1 | Continued

\begin{tabular}{|c|c|c|c|c|c|c|c|}
\hline Chemical & $\begin{array}{l}\text { LOAEL for } \\
\text { the study }\end{array}$ & $\begin{array}{l}\text { Experimental } \\
\text { model }\end{array}$ & $\begin{array}{c}\text { Age at } \\
\text { beginning } \\
\text { of exposure }\end{array}$ & Exposure duration & Exposure route & Main results & Reference \\
\hline & & & & & & $\begin{array}{l}\text { experimental period } \\
\text { Low dose } \\
\text { individuals in the first } \\
\text { exposure period } \\
\text { group developed } \\
\text { slower } \\
\text { High dose } \\
\downarrow \text { Body mass in the } \\
\text { 1st, 4th, and 5th } \\
\text { period } \\
\text { Individuals in the } \\
\text { 1st,2nd, 3rd, 4th } \\
\text { exposure period } \\
\text { group developed } \\
\text { slower }\end{array}$ & \\
\hline $\begin{array}{l}\text { GBH (Roundup1UltraMax and } \\
\text { Focus Ultra, Monsanto Co.) }\end{array}$ & $13.5 \mathrm{mg} / \mathrm{L}$ & Tadpoles & GS 25 & $96 \mathrm{~h}$ & Water (aquaria) & $\begin{array}{l}\text { Delayed } \\
\text { metamorphosis }\end{array}$ & $\begin{array}{l}\text { Wagner } \\
\text { et al. (93) }\end{array}$ \\
\hline GBH (Roundup original $\left.{ }^{\circledR} \mathrm{DI}\right)$ & $144 \mu g / L$ & Tadpoles & GS 25-26 & $\begin{array}{l}\text { acute assay: } 96 \mathrm{~h} \\
\text { chronic assay: } 14 \text { days }\end{array}$ & Water (aquaria) & $\begin{array}{l}\text { Tadpoles showed } \\
\text { shorter lengths and } \\
\text { lower masses } \\
\uparrow \text { Malformation in the } \\
\text { mouth, the } \\
\text { epithelium color and } \\
\text { bowel edema }\end{array}$ & $\begin{array}{l}\text { Herek } \\
\text { et al. (94) }\end{array}$ \\
\hline $\begin{array}{l}\text { GBH (Roundup }{ }^{\circledR} \text { Star) or } \\
\text { Glyphosate (PESTANAL }{ }^{\circledR} \text {, } \\
\text { analytic grade, } 45521 \text {, Sigma- } \\
\text { Aldrich) }\end{array}$ & $\begin{array}{l}\text {-Stage 8: } 37.8 \\
\text { mg active } \\
\text { ingredient } \mathrm{L}^{-1} \\
\text { for embryos } \\
\text {-Stage } 46 \text { : } \\
45.1 \mathrm{mg} \\
\text { active } \\
\text { ingredient } \mathrm{L}^{-1} \\
\text { for tadpoles }\end{array}$ & $\begin{array}{l}\text { Embryos and } \\
\text { tadpoles }\end{array}$ & $\begin{array}{l}\text {-FETAX test: } \\
\text { stage } 8 \\
\text { embryos } \\
\text {-Tadpole- } \\
\text { toxicity } \\
\text { bioassays: } \\
\text { stage } 46\end{array}$ & $24,48,72$ and $96 \mathrm{~h}$ & $\begin{array}{l}\text { Water/in a standard } \\
\text { Frog Embryo } \\
\text { Teratogenesis Assay } \\
\text { Xenopus (FETAX) test } \\
\text { medium }\end{array}$ & $\begin{array}{l}\text { GBH: } \\
\text { Significant inhibition } \\
\text { of embryonic growth } \\
\downarrow \text { Activity of GR, CaE, } \\
\text { AChE, and SOD }\end{array}$ & $\begin{array}{l}\text { Turhan } \\
\text { et al. (95) }\end{array}$ \\
\hline
\end{tabular}

GBH is able to affect the intestinal microbiome of mice (106), rats (107-112), honeybees (113, 114), Japanese quails (115) and Daphnia magna (116). A possible explanation for this toxicity is that some classes of bacteria require the shikimate pathway (5enolpyruvylshikimate-3-phosphate synthase, EPSPS) for their metabolism. The glyphosate mechanism of action is through inhibition of the growth of weeds by interfering with the production of essential aromatic amino acids by inhibiting EPSPS, which is responsible for chorismate biosynthesis, an intermediate in the biosynthesis of phenylalanine, tyrosine and tryptophan (7). Then, from the moment glyphosate inhibits it, these bacteria are unable to maintain normal levels in the gut microbiome (111, 113-115). Thus, new studies evaluating the involvement of the gut-thyroid axis are relevant in advancing the knowledge of glyphosate toxicity on thyroid function.

\section{FINAL CONSIDERATIONS}

The toxicity of glyphosate on thyroid function and its participation in the increasing incidence of thyroid diseases is still a very controversial subject. The main points of this review were:

- The regulation of the HPT axis is very complex, with several steps that can be affected by xenobiotics;

- The HPT axis has the capacity to adapt to different stress situations (allostasis), confusing the interpretation of EDC effects;

- The synthesis of THs depends on the formation of $\mathrm{H}_{2} \mathrm{O}_{2}$, and the ROS formed are neutralized mainly by selenoproteins;

- Glyphosate has a high probability of binding to anions and cations in $\mathrm{pH}$ compatible with those observed in body compartments; the real occurrence/extension/consequences of this effect should be evaluated experimentally;

- Glyphosate alters the absorption of selenium, the functioning of the $\mathrm{Ca}^{++}$channels and disrupts oxidative phosphorylation, thus it can affect the thyroid function;

- Oxidative stress is present in autoimmune thyroiditis and thyroid carcinomas;

- The HPT axis is recognized as the target of EDCs; 
TABLE 2 | Summary of the thyroid toxic effects after glyphosate or glyphosate-based herbicides (GBH) exposure in rats and mice.

\begin{tabular}{|c|c|c|c|c|c|c|c|}
\hline Chemical & $\begin{array}{l}\text { LOAEL } \\
\text { for the } \\
\text { study }\end{array}$ & Experimental model & $\begin{array}{l}\text { Age at beginning } \\
\text { of exposure }\end{array}$ & $\begin{array}{l}\text { Exposure } \\
\text { duration }\end{array}$ & $\begin{array}{l}\text { Exposure } \\
\text { route }\end{array}$ & Main results & Reference \\
\hline $\begin{array}{l}\text { GBH (Roundup Transorb, } \\
\text { Monsanto Co.) }\end{array}$ & $5 \mathrm{mg} / \mathrm{kg}$ & $\begin{array}{l}\text { o Wistar rats (adult male } \\
\text { offspring from dams treated } \\
\text { with } \mathrm{GBH} \text { ) }\end{array}$ & $\begin{array}{l}\text { Gestational day } 18 \\
\text { to postnatal day } 5\end{array}$ & 10 days & $\begin{array}{l}\text { Gavage } \\
\text { to the } \\
\text { mothers }\end{array}$ & $\begin{array}{l}\downarrow T S H \\
\text { Altered expression of several } \\
\text { genes related to thyroid } \\
\text { function } \\
\text { Metabolomics changes similar } \\
\text { to hypothyroidism }\end{array}$ & $\begin{array}{l}\text { de Souza } \\
\text { et al. (96) }\end{array}$ \\
\hline $\begin{array}{l}\text { GBH (Roundup Bioflow, } \\
\text { Monsanto Co.) and } \\
\text { glyphosate }\end{array}$ & $\begin{array}{c}1.75 \mathrm{mg} / \\
\mathrm{kg}\end{array}$ & ¡o Sprague-Dawley rats & $\begin{array}{l}\text { Gestational day } 6 \\
\text { to postnatal day } \\
120\end{array}$ & $\begin{array}{l}6 \text { weeks or } \\
13 \text { weeks }\end{array}$ & $\begin{array}{l}\text { Drinking } \\
\text { water }\end{array}$ & $\begin{array}{l}\uparrow \mathrm{TSH} \text { ð (glyphosate-6 } \\
\text { weeks) } \\
\uparrow \mathrm{TSH} \text { ð(GBH-13 weeks) }\end{array}$ & $\begin{array}{l}\text { Manservisi } \\
\text { et al. (97) }\end{array}$ \\
\hline $\begin{array}{l}\text { GBH (Kalach } 360 \text { SL, } \\
\text { Monsanto Co.) }\end{array}$ & 126 mg/kg & o Wistar rats & Not informed & 60 days & Gavage & $\begin{array}{l}\uparrow \mathrm{TSH} \\
\downarrow F T 3 \text { and FT4 } \\
\downarrow \text { colloid volume in thyroid } \\
\downarrow \text { calcitonin }\end{array}$ & $\begin{array}{l}\text { Hamdaoui } \\
\text { et al. (98) }\end{array}$ \\
\hline $\begin{array}{l}\text { GBH (brand not } \\
\text { mentioned) }\end{array}$ & 250 mg/kg & q Kunming Mice & Four-week-old & 7 days & Intragastric & $\begin{array}{l}\uparrow \text { TRH serum } \\
\downarrow \text { TSH, T3 and T4 serum } \\
\downarrow \text { Relative expression of Dio2 } \\
\text { and Mct8 in the hypothalamus } \\
\uparrow \text { Relative expression of Dio2, } \\
\text { Mct8 and Trhr in the pituitary } \\
\downarrow \text { Relative expression of Nis, } \\
\text { Tpo, Tg and Tshr in thyroid } \\
\text { tissue }\end{array}$ & $\begin{array}{l}\text { Zhang } \\
\text { et al. (99) }\end{array}$ \\
\hline
\end{tabular}

TABLE 3 | Summary of the thyroid toxic effects after glyphosate-based herbicides (GBH) exposure in human.

\begin{tabular}{|c|c|c|c|c|c|}
\hline Gender & $\begin{array}{l}\text { Age at beginning of } \\
\text { exposure }\end{array}$ & Exposure duration & Exposure route & Main results & Reference \\
\hline $90^{*}$ & 50-53 years old & February-December 2016 & $\begin{array}{l}\text { Occupational } \\
\text { exposure }\end{array}$ & $\uparrow$ Levels of T4 & $\begin{array}{l}\text { Kongtip et al. } \\
\text { (13) }\end{array}$ \\
\hline o & $43.9 \pm 11.5$ years old & $\begin{array}{l}\text { The study was conducted during the high exposure period } \\
\text { to pesticides }\end{array}$ & $\begin{array}{l}\text { Occupational } \\
\text { exposure }\end{array}$ & $\begin{array}{l}\downarrow \text { TSH } \\
\uparrow \mathrm{T} 3 \text { and T4 }\end{array}$ & $\begin{array}{l}\text { Bernieri et al. } \\
(100)\end{array}$ \\
\hline 90 & $\leq 45$ years to 65 & 1999-2016 & $\begin{array}{l}\text { Occupational } \\
\text { exposure }\end{array}$ & $\begin{array}{l}\text { Elevated risk of } \\
\text { hypothyroidism }\end{array}$ & $\begin{array}{l}\text { Shrestha et al. } \\
\text { (12) }\end{array}$ \\
\hline
\end{tabular}

- Commercial formulations (GBH) are more toxic than glyphosate;

- Few thyroid toxicology studies have been performed to date;

- In tests validated by regulatory agencies, the thyroid changes presented are disregarded, since allostatic regulation is observed;

- Glyphosate is detected in the urine of residents of rural and urban environments;

- There is a correlation between farmers' exposure to GBHs and altered thyroid hormone levels or incidence of thyroid pathologies;

That presented, two conclusions appear to be more important: (1) there are few studies evaluating the mechanisms of toxicity (where, how and if it occurs), which makes the extrapolation of correlations between human exposure and toxicity somehow fragile; (2) It might be time to start considering testing the toxicity of commercial formulations, as these represent the actual human and environmental exposure.

\section{AUTHOR CONTRIBUTIONS}

RM and MR contributed to conception and design of the review. IO and PB-S wrote the section The Maintenance of Hypothalamus-Pituitary-Thyroid Axis Homeostasis and Its Allostasis-Adaptive Responses. RM, MR, and YT wrote the section Thyroid Hormones Synthesis Pathway as a Possible Target to Toxicants. VD, RM, and MR wrote the section Glyphosate Toxicity in HPT Axis. JD, RM, and MR wrote the section Future Perspectives. RM, MR, and AM wrote the sections Introduction and Final Considerations. All authors contributed to the article and approved the submitted version.

\section{FUNDING}

JMO was recipient of scholarship instead (Coordenação de Aperfeiçoamento de Pessoal de Nivel Superior-Brasil [CAPES]-Finance Code 001). RMR is recipient of Conselho Nacional de Desenvolvimento Científico e Tecnológico- BRASIL productivity grant (CNPq 09/2020, \# 309256/2020-8) 


\section{REFERENCES}

1. Huhtaniemi I, Martini L. Endocrinology - Study of the Hormonal Regulation of the Body. In: Reference Module in Biomedical Sciences. Amsterdam, NL: Elsevier. (2015). p. 1-4 doi: 10.1016/B978-0-12-8012383.07829-6

2. Taylor PN, Albrecht D, Scholz A, Gutierrez-Buey G, Lazarus JH, Dayan CM, et al. Global epidemiology of hyperthyroidism and hypothyroidism. Nat Rev Endocrinol (2018) 14:301-16. doi: 10.1038/nrendo.2018.18

3. McLeod DS, Cooper DS. The incidence and prevalence of thyroid autoimmunity. Endocrine (2012) 42:252-65. doi: 10.1007/s12020-0129703-2

4. Dong YH, Fu DG. Autoimmune thyroid disease: mechanism, genetics and current knowledge. Eur Rev Med Pharmacol Sci (2014) 18:3611-18.

5. Kim J, Gosnell JE, Roman SA. Geographic influences in the global rise of thyroid cancer. Nat Rev Endocrinol (2020) 16:17-29. doi: 10.1038/s41574019-0263-x

6. Romano RM, Romano MA, de Oliveira CA. Glifosato como desregulador endócrino químico Glyphosate as an endocrine chemical disruptor. Ambiência (2009) 5:359-72.

7. Agency for Toxic Substances and Disease Registry A. Toxicological profile for Glyphosate. Atlanta, GA: U.S. Department of Health and Human Services, Public Health Service (2019). 257p.

8. IBAMA. Relatórios de Comercialização de Agrotóxicos - Boletim Anual de Produção, Importação, Exportação e Vendas de Agrotóxicos no Brasil Vol. 2014. . Brasília, DF: Instituto Brasileiro do Meio Ambiente e dos Recursos Naturais Renováveis, Diretoria de Qualidade Ambiental.; Boletins (2009).

9. Gillezeau C, van Gerwen M, Shaffer RM, Rana I, Zhang L, Sheppard L, et al. The evidence of human exposure to glyphosate: a review. Environ Health (2019) 18:2. doi: 10.1186/s12940-018-0435-5

10. Samsel A, Seneff S. Glyphosate, pathways to modern diseases II: Celiac sprue and gluten intolerance. Interdiscip Toxicol (2013) 6:159-84. doi: 10.2478/ intox-2013-0026

11. Knezevic J, Starchl C, Tmava Berisha A, Amrein K. Thyroid-Gut-Axis: How Does the Microbiota Influence Thyroid Function? Nutrients (2020) 12:1769. doi: 10.3390/nu12061769

12. Shrestha S, Parks CG, Goldner WS, Kamel F, Umbach DM, Ward MH, et al. Pesticide Use and Incident Hypothyroidism in Pesticide Applicators in the Agricultural Health Study. Environ Health Perspect (2018) 126:97008. doi: 10.1289/EHP3194

13. Kongtip P, Nankongnab N, Kallayanatham N, Pundee R, Choochouy N, Yimsabai J, et al. Thyroid Hormones in Conventional and Organic Farmers in Thailand. Int J Environ Res Public Health (2019) 16:2704. doi: 10.3390/ ijerph16152704

14. EFSA. Peer review of the pesticide risk assessment of the potential endocrine disrupting properties of glyphosate. Efsa J (2017) 15:e04979. doi: 10.2903/ j.efsa.2017.4979

15. Leon ME, Schinasi LH, Lebailly P, Beane Freeman LE, Nordby KC, Ferro G, et al. Pesticide use and risk of non-Hodgkin lymphoid malignancies in agricultural cohorts from France, Norway and the USA: a pooled analysis from the AGRICOH consortium. Int J Epidemiol (2019) 48:1519-35. doi: 10.1093/ije/dyz017

16. Myers JP, Antoniou MN, Blumberg B, Carroll L, Colborn T, Everett LG, et al. Concerns over use of glyphosate-based herbicides and risks associated with exposures: a consensus statement. Environ Health (2016) 15:19. doi: 10.1186/s12940-016-0117-0

17. Zhang L, Rana I, Shaffer RM, Taioli E, Sheppard L. Exposure to glyphosatebased herbicides and risk for non-Hodgkin lymphoma: a meta-analysis and supporting evidence. Mutat Res (2019) 781:186-206. doi: 10.1016/ j.mrrev.2019.02.001

18. IARC. SOME ORGANOPHOSPHATE INSECTICIDES AND HERBICIDES (2015). Available at: https://publications.iarc.fr/549 (Accessed November 10, 2020).

19. Andreotti G, Koutros S, Hofmann JN, Sandler DP, Lubin JH, Lynch CF, et al. Glyphosate Use and Cancer Incidence in the Agricultural Health Study. J Natl Cancer Inst (2017) 110:509-16. doi: 10.1093/jnci/djx233

20. Beckie HJ, Flower KC, Ashworth MB. Farming without Glyphosate? Plants (Basel) (2020) 9:96. doi: 10.3390/plants9010096
21. Van Bruggen AHC, He MM, Shin K, Mai V, Jeong KC, Finckh MR, et al. Environmental and health effects of the herbicide glyphosate. Sci Total Environ (2018) 616-617:255-68. doi: 10.1016/j.scitotenv.2017.10.309

22. Guyton KZ, Ghissassi FE, Ghissassi FE, Benbrahim-Talaa L, Grosse Y, Loomis D, et al. Research, Education and Policy in Concert. Recent Progress in Mechanistic Data Evaluation: The IARC Monographs Perspective, in: Abstracts from the Environmental Mutagenesis and Genomics Society 46th Annual Meeting, New Orleans, Louisiana, September 26-30. New Jersey, USA: Wiley Online Library, Hoboken (2015). pp. p.1-91. doi: 10.1002/em.21969

23. Yu R, Ashworth R, Hinkle PM. Receptors for thyrotropin-releasing hormone on rat lactotropes and thyrotropes. Thyroid (1998) 8:887-94. doi: 10.1089/ thy.1998.8.887

24. Harris AR, Christianson D, Smith MS, Fang SL, Braverman LE, Vagenakis AG. The physiological role of thyrotropin-releasing hormone in the regulation of thyroid-stimulating hormone and prolactin secretion in the rat. J Clin Invest (1978) 61:441-48. doi: 10.1172/JCI108955

25. Chiamolera MI, Wondisford FE. Thyrotropin-Releasing Hormone and the Thyroid Hormone Feedback Mechanism. Endocrinology (2009) 150:109196. doi: 10.1210/en.2008-1795

26. Szkudlinski MW, Fremont V, Ronin C, Weintraub BD. Thyroid-stimulating hormone and thyroid-stimulating hormone receptor structure-function relationships. Physiol Rev (2002) 82:473-502. doi: 10.1152/ physrev.00031.2001

27. Carvalho DP, Dupuy C. Thyroid hormone biosynthesis and release. Mol Cell Endocrinol (2017) 458:6-15. doi: 10.1016/j.mce.2017.01.038

28. Citterio CE, Targovnik HM, Arvan P. The role of thyroglobulin in thyroid hormonogenesis. Nat Rev Endocrinol (2019) 15:323-38. doi: 10.1038/ s41574-019-0184-8

29. Grijota-Martinez C, Barez-Lopez S, Gomez-Andres D, Guadano-Ferraz A MCT8 Deficiency: The Road to Therapies for a Rare Disease. Front Neurosci (2020) 14:380:380. doi: 10.3389/fnins.2020.00380

30. van der Deure WM, Peeters RP, Visser TJ. Molecular aspects of thyroid hormone transporters, including MCT8, MCT10, and OATPs, and the effects of genetic variation in these transporters. J Mol Endocrinol (2010) 44:1-11. doi: 10.1677/JME-09-0042

31. Friesema EC, Ganguly S, Abdalla A, Manning Fox JE, Halestrap AP, Visser TJ. Identification of monocarboxylate transporter 8 as a specific thyroid hormone transporter. J Biol Chem (2003) 278:40128-35. doi: 10.1074/ jbc.M300909200

32. Mendoza A, Hollenberg AN. New insights into thyroid hormone action. Pharmacol Ther (2017) 173:135-45. doi: 10.1016/j.pharmthera.2017.02.012

33. Cheng SY, Leonard JL, Davis PJ. Molecular aspects of thyroid hormone actions. Endocr Rev (2010) 31:139-70. doi: 10.1210/er.2009-0007

34. Ortiga-Carvalho TM, Sidhaye AR, Wondisford FE. Thyroid hormone receptors and resistance to thyroid hormone disorders. Nat Rev Endocrinol (2014) 10:582-91. doi: 10.1038/nrendo.2014.143

35. Davis PJ, Goglia F, Leonard JL. Nongenomic actions of thyroid hormone Nat Rev Endocrinol (2016) 12:111-21. doi: 10.1038/nrendo.2015.205

36. Dietrich JW, Landgrafe G, Fotiadou EH. TSH and Thyrotropic Agonists: Key Actors in Thyroid Homeostasis. J Thyroid Res (2012) 2012:351864. doi: 10.1155/2012/351864

37. Fekete C, Lechan RM. Negative feedback regulation of hypophysiotropic thyrotropin-releasing hormone (TRH) synthesizing neurons: role of neuronal afferents and type 2 deiodinase. Front Neuroendocrinol (2007) 28:97-114. doi: 10.1016/j.yfrne.2007.04.002

38. Chatzitomaris A, Hoermann R, Midgley JE, Hering S, Urban A, Dietrich B et al. Thyroid Allostasis-Adaptive Responses of Thyrotropic Feedback Control to Conditions of Strain, Stress, and Developmental Programming. Front Endocrinol (Lausanne) (2017) 8:163. doi: 10.3389/fendo.2017.00163

39. Matoso de Oliveira V, Ivanski F, Medeiros de Oliveira I, Bargi-Souza P, Luiz Schiessel D, Aurelio Romano M, et al. Acrylamide induces a thyroid allostasis-adaptive response in prepubertal exposed rats. Curr Res Toxicol (2020) 1:124-32. doi: 10.1016/j.crtox.2020.10.003

40. de Oliveira IM, Cavallin MD, Corrêa DEDC, Razera A, Mariano DD, Ferreira F, et al. Proteomic Profiles of Thyroid Gland and Gene Expression of the Hypothalamic-Pituitary-Thyroid Axis Are Modulated 
by Exposure to AgNPs during Prepubertal Rat Stages. Chem Res Toxicol (2020) 33:2605-22. doi: 10.1021/acs.chemrestox.0c00250

41. Berberich J, Dietrich JW, Hoermann R, Muller MA. Mathematical Modeling of the Pituitary-Thyroid Feedback Loop: Role of a TSH-T3-Shunt and Sensitivity Analysis. Front Endocrinol (Lausanne) (2018) 9:91. doi: 10.3389/fendo.2018.00091

42. Ghassabian A, Trasande L. Disruption in Thyroid Signaling Pathway: A Mechanism for the Effect of Endocrine-Disrupting Chemicals on Child Neurodevelopment. Front Endocrinol (Lausanne) (2018) 9:204. doi: 10.3389/ fendo.2018.00204

43. Krohn K, Paschke R. Chapter 57 - Iodine Deficiency, Antioxidant Response and Mutagenesis in the Thyroid Gland: Antioxidant Response and Mutagenesis. In: VR Preedy, GN Burrow, R Watson, editors. Comprehensive Handbook of Iodine. San Diego: Academic Press (2009). p. 549-58.

44. Soundarrajan M, Kopp PA. Thyroid Hormone Biosynthesis and Physiology. In: Thyroid Disease and Reproduction. New York, USA: Springer (2019). p. 1-17.

45. Fagerberg L, Hallström BM, Oksvold P, Kampf C, Djureinovic D, Odeberg J, et al. Analysis of the human tissue-specific expression by genome-wide integration of transcriptomics and antibody-based proteomics. Mol Cell Proteomics (2014) 13:397-406. doi: 10.1074/mcp.M113.035600

46. Gheorghiu ML, Badiu C. Selenium involvement in mitochondrial function in thyroid disorders. Hormones (Athens) (2020) 19:25-30. doi: 10.1007/ s42000-020-00173-2

47. Metere A, Graves CE, Chirico M, Caramujo MJ, Pisanu ME, Iorio E. Metabolomic Reprogramming Detected by (1)H-NMR Spectroscopy in Human Thyroid Cancer Tissues. Biol (Basel) (2020) 9:112. doi: 10.3390/ biology 9060112

48. Nelson D, Cox M. Lehninger principles of biochemistry. internat. ed Vol. 6. New York: Freeman (2013). 1298p.

49. Wilson DF. Oxidative phosphorylation: regulation and role in cellular and tissue metabolism. J Physiol (2017) 595:7023-38. doi: 10.1113/JP273839

50. Pizzino G, Irrera N, Cucinotta M, Pallio G, Mannino F, Arcoraci V, et al. Oxidative Stress: Harms and Benefits for Human Health. Oxid Med Cell Longev (2017) 2017:8416763. doi: 10.1155/2017/8416763

51. McCully KS. Environmental Pollution, Oxidative Stress and Thioretinaco Ozonide: Effects of Glyphosate, Fluoride and Electromagnetic Fields on Mitochondrial Dysfunction in Carcinogenesis, Atherogenesis and Aging. Ann Clin Lab Sci (2020) 50:408-11.

52. Paul S, Meggitt WF, Donald P. Adsorption, Mobility, and Microbial Degradation of Glyphosate in the Soil. Weed Sci (1975) 23:229-34. doi: $10.1017 /$ S0043174500052929

53. https://pubchem.ncbi.nlm.nih.gov/compound/3496. PubChem Compound Database; $\mathrm{CID}=3496$ [Internet]. Available from.

54. Huang C-J. 5 - Advanced surface modification technologies for biosensors. In: K Mitsubayashi, O Niwa, Y Ueno, editors. Chemical, Gas, and Biosensors for Internet of Things and Related Applications. Amsterdam, NL: Elsevier (2019). p. 65-86.

55. Villemin D, Didi MA. Aminomethylenephosphonic acids syntheses and applications (A Review). Oriental J Chem (Special Issue) (2015) 31:01-12. doi: $10.13005 / \mathrm{ojc} / 31$

56. Coutinho CF, Mazo LH. Complexos metálicos com o herbicida glifosato: revisão. Quimica Nova (2005) 28:1038-45. doi: 10.1590/S010040422005000600019

57. Cáceres-Jensen L, Gan J, Báez M, Fuentes R, Escudey M. Adsorption of glyphosate on variable-charge, volcanic ash-derived soils. J Environ Qual (2009) 38:1449-57. doi: 10.2134/jeq2008.0146

58. Subramaniam V, Hoggard PE. Metal complexes of glyphosate. J Agric Food Chem (1988) 36:1326-29. doi: 10.1021/jf00084a050

59. Sagatys DS, Dahlgren C, Smith G, Bott RC, White JM. The complex chemistry of $\mathrm{N}$-(phosphonomethyl) glycine (glyphosate): preparation and characterization of the ammonium, lithium, sodium (4 polymorphs) and silver (I) complexes. J Chem Soc Dalton Trans (2000) 19:3404-10. doi: $10.1039 / \mathrm{b} 002748 \mathrm{k}$

60. Nicola JP, Carrasco N, Masini-Repiso AM. Chapter One - Dietary IAbsorption: Expression and Regulation of the Na+/I- Symporter in the Intestine. In: G Litwack, editor. Vitamins \& Hormones, vol. 98. Cambridge, USA: Academic Press (2015). p. 1-31.
61. Mertens M, Höss S, Neumann G, Afzal J, Reichenbecher W. Glyphosate, a chelating agent-relevant for ecological risk assessment? Environ Sci Pollut Res Int (2018) 25:5298-317. doi: 10.1007/s11356-017-1080-1

62. Tsui MTK, Wang W-X, Chu LM. Influence of glyphosate and its formulation (Roundup ${ }^{\circledR}$ ) on the toxicity and bioavailability of metals to Ceriodaphnia dubia. Environ Pollut (2005) 138:59-68. doi: 10.1016/ j.envpol.2005.02.018

63. Duke SO, Lydon J, Koskinen WC, Moorman TB, Chaney RL, Hammerschmidt R. Glyphosate effects on plant mineral nutrition, crop rhizosphere microbiota, and plant disease in glyphosate-resistant crops. J Agric Food Chem (2012) 60:10375-97. doi: 10.1021/jf302436u

64. Olorunsogo OO. Modification of the transport of protons and $\mathrm{Ca} 2+$ ions across mitochondrial coupling membrane by $\mathrm{N}$-(phosphonomethyl)glycine. Toxicology (1990) 61:205-9. doi: 10.1016/0300-483x(90)90021-8

65. de Liz Oliveira Cavalli VL, Cattani D, Heinz Rieg CE, Pierozan P, Zanatta L, Benedetti Parisotto E, et al. Roundup disrupts male reproductive functions by triggering calcium-mediated cell death in rat testis and Sertoli cells. Free Radic Biol Med (2013) 65:335-46. doi: 10.1016/j.freeradbiomed.2013.06.043

66. Cox C, Surgan M. Unidentified inert ingredients in pesticides: implications for human and environmental health. Environ Health Perspect (2006) 114:1803-6. doi: 10.1289/ehp.9374

67. Levine SL, Webb EG, Saltmiras DA. Review and analysis of the potential for glyphosate to interact with the estrogen, androgen and thyroid pathways. Pest Manag Sci (2020) 76:2886-906. doi: 10.1002/ps.5983

68. Agostini LP, Dettogni RS, Dos Reis RS, Stur E, Dos Santos EVW, Ventorim DP, et al. Effects of glyphosate exposure on human health: Insights from epidemiological and in vitro studies. Sci Total Environ (2020) 705:135808. doi: 10.1016/j.scitotenv.2019.135808

69. Kuś A, Chaker L, Teumer A, Peeters RP, Medici M. The Genetic Basis of Thyroid Function: Novel Findings and New Approaches. J Clin Endocrinol Metab (2020) 105:dgz225. doi: 10.1210/clinem/dgz225

70. Hernández AF, Bennekou SH, Hart A, Mohimont L, Wolterink G. Mechanisms underlying disruptive effects of pesticides on the thyroid function. Curr Opin Toxicol (2020) 19:34-41. doi: 10.1016/j.cotox. 2019.10.003

71. Leemans M, Couderq S, Demeneix B, Fini J-B. Pesticides With Potential Thyroid Hormone-Disrupting Effects: A Review of Recent Data. Front Endocrinol (Lausanne) (2019) 10:743. doi: 10.3389/ fendo.2019.00743

72. Pistollato F, Masias M, Agudo P, Giampieri F, Battino M. Effects of phytochemicals on thyroid function and their possible role in thyroid disease. Ann N Y Acad Sci (2019) 1443:3-19. doi: 10.1111/nyas.13980

73. Mughal BB, Fini JB, Demeneix BA. Thyroid-disrupting chemicals and brain development: an update. Endocr Connect (2018) 7:r160-r86. doi: 10.1530/ EC-18-0029

74. Demeneix BA. Evidence for Prenatal Exposure to Thyroid Disruptors and Adverse Effects on Brain Development. Eur Thyroid J (2019) 8:283-92. doi: $10.1159 / 000504668$

75. Boas M, Feldt-Rasmussen U, Main KM. Thyroid effects of endocrine disrupting chemicals. Mol Cell Endocrinol (2012) 355:240-8. doi: 10.1016/ j.mce.2011.09.005

76. de Cock M, de Boer MR, Lamoree M, Legler J, van de Bor M. Prenatal exposure to endocrine disrupting chemicals in relation to thyroid hormone levels in infants - a Dutch prospective cohort study. Environ Health (2014) 13:106. doi: 10.1186/1476-069X-13-106

77. Coperchini F, Awwad O, Rotondi M, Santini F, Imbriani M, Chiovato L. Thyroid disruption by perfluorooctane sulfonate (PFOS) and perfluorooctanoate (PFOA). J Endocrinol Invest (2017) 40:105-21. doi: 10.1007/s40618-016-0572-z

78. Benvenga S, Elia G, Ragusa F, Paparo SR, Sturniolo MM, Ferrari SM, et al. Endocrine disruptors and thyroid autoimmunity. Best Pract Res Clin Endocrinol Metab (2020) 34:101377. doi: 10.1016/j.beem.2020.101377

79. Sur U, Erkekoglu P, Bulus AD, Andiran N, Kocer-Gumusel B. Oxidative stress markers, trace elements, and endocrine disrupting chemicals in children with Hashimoto's thyroiditis. Toxicol Mech Methods (2019) 29:633-43. doi: 10.1080/15376516.2019.1646367

80. Liu S, Zhao G, Li J, Zhao H, Wang Y, Chen J, et al. Association of polybrominated diphenylethers (PBDEs) and hydroxylated metabolites 
(OH-PBDEs) serum levels with thyroid function in thyroid cancer patients. Environ Res (2017) 159:1-8. doi: 10.1016/j.envres.2017.07.042

81. Mughal BB, Demeneix BA. Flame retardants and increased risk of thyroid cancer. Nat Rev Endocrinol (2017) 13:627-28. doi: 10.1038/ nrendo.2017.123

82. Stojsavljević A, Rovčanin B, Krstić Đ, Jagodić J, Borković-Mitić S, Paunović I, et al. Cadmium as main endocrine disruptor in papillary thyroid carcinoma and the significance of $\mathrm{Cd} / \mathrm{Se}$ ratio for thyroid tissue pathophysiology. J Trace Elem Med Biol (2019) 55:190-5. doi: 10.1016/ j.jtemb.2019.06.009

83. Howe CM, Berrill M, Pauli BD, Helbing CC, Werry K, Veldhoen N. Toxicity of glyphosate-based pesticides to four North American frog species. Environ Toxicol Chem (2004) 23:1928-38. doi: 10.1897/03-71

84. Vandenberg LN. Endocrine CHAPTER6 Disruptors and Other Environmental Influences on Hormone Action. In: The Oxford Handbook of Evolutionary Psychology and Behavioral Endocrinology. Oxford, England: Oxford University Press (2019). p. 87p. doi: 10.1093/oxfordhb/ 9780190649739.001.0001

85. Babalola OO, Truter JC, Archer E, van Wyk JH. Exposure Impacts of Environmentally Relevant Concentrations of a Glufosinate Ammonium Herbicide Formulation on Larval Development and Thyroid Histology of Xenopus laevis. Arch Environ Contam Toxicol (2020). doi: 10.1007/s00244020-00758-3

86. Ruthsatz K, Dausmann KH, Reinhardt S, Robinson T, Sabatino NM, Peck MA, et al. Post-metamorphic carry-over effects of altered thyroid hormone level and developmental temperature: physiological plasticity and body condition at two life stages in Rana temporaria. J Comp Physiol B (2020) 190:297-315. doi: 10.1007/s00360-020-01271-8

87. Lanctot C, Robertson C, Navarro-Martin L, Edge C, Melvin SD, Houlahan J, et al. Effects of the glyphosate-based herbicide Roundup WeatherMax(R) on metamorphosis of wood frogs (Lithobates sylvaticus) in natural wetlands. Aquat Toxicol (2013) 140-141:48-57. doi: 10.1016/j.aquatox.2013.05.012

88. Navarro-Martín L, Lanctôt C, Jackman P, Park BJ, Doe K, Pauli BD, et al. Effects of glyphosate-based herbicides on survival, development, growth and sex ratios of wood frogs (Lithobates sylvaticus) tadpoles. I: chronic laboratory exposures to VisionMax ${ }^{\circledR}$. Aquat Toxicol (2014) 154:278-90. doi: 10.1016/j.aquatox.2014.05.017

89. Vincent K, Davidson C. The toxicity of glyphosate alone and glyphosatesurfactant mixtures to western toad (Anaxyrus boreas) tadpoles. Environ Toxicol Chem (2015) 34:2791-5. doi: 10.1002/etc.3118

90. Bach NC, Natale GS, Somoza GM, Ronco AE. Effect on the growth and development and induction of abnormalities by a glyphosate commercial formulation and its active ingredient during two developmental stages of the South-American Creole frog, Leptodactylus latrans. Environ Sci Pollut Res Int (2016) 23:23959-971. doi: 10.1007/s11356-016-7631-z

91. Dornelles MF, Oliveira GT. Toxicity of atrazine, glyphosate, and quinclorac in bullfrog tadpoles exposed to concentrations below legal limits. Environ Sci Pollut Res Int (2016) 23:1610-20. doi: 10.1007/s11356-015-5388-4

92. Miko Z, Ujszegi J, Hettyey A. Age-dependent changes in sensitivity to a pesticide in tadpoles of the common toad (Bufo bufo). Aquat Toxicol (2017) 187:48-54. doi: 10.1016/j.aquatox.2017.03.016

93. Wagner N, Muller H, Viertel B. Effects of a commonly used glyphosatebased herbicide formulation on early developmental stages of two anuran species. Environ Sci Pollut Res Int (2017) 24:1495-508. doi: 10.1007/s11356016-7927-z

94. Herek JS, Vargas L, Trindade SAR, Rutkoski CF, Macagnan N, Hartmann $\mathrm{PA}$, et al. Can environmental concentrations of glyphosate affect survival and cause malformation in amphibians? Effects from a glyphosate-based herbicide on Physalaemus cuvieri and P. gracilis (Anura: Leptodactylidae). Environ Sci Pollut Res Int (2020) 27:22619-630. doi: 10.1007/s11356-02008869-z

95. Turhan D, Güngördü A, Ozmen M. Developmental and lethal effects of glyphosate and a glyphosate-based product on Xenopus laevis embryos and tadpoles. Bull Environ Contam Toxicol (2020) 104:173-79. doi: 10.1007/ s00128-019-02774-z

96. de Souza JS, Kizys MM, da Conceicao RR, Glebocki G, Romano RM, OrtigaCarvalho TM, et al. Perinatal exposure to glyphosate-based herbicide alters the thyrotrophic axis and causes thyroid hormone homeostasis imbalance in male rats. Toxicology (2017) 377:25-37. doi: 10.1016/j.tox.2016.11.005

97. Manservisi F, Lesseur C, Panzacchi S, Mandrioli D, Falcioni L, Bua L, et al. The Ramazzini Institute 13-week pilot study glyphosate-based herbicides administered at human-equivalent dose to Sprague Dawley rats: effects on development and endocrine system. Environ Health (2019) 18:15. doi: 10.1186/s12940-019-0453-y

98. Hamdaoui L, Oudadesse H, Lefeuvre B, Mahmoud A, Naifer M, Badraoui R, et al. Sub-chronic exposure to Kalach 360 SL, Glyphosate-based Herbicide, induced bone rarefaction in female Wistar rats. Toxicology (2020) 436:152412. doi: 10.1016/j.tox.2020.152412

99. Zhang J, Zhao C, Shi F, Zhang S, Wang S, Feng X. Melatonin alleviates the deterioration of oocytes and hormonal disorders from mice subjected to glyphosate. Mol Cell Endocrinol (2020) 520:111073. doi: 10.1016/j.mce.2020.111073

100. Bernieri T, Rodrigues D, Barbosa IR, Ardenghi PG, Basso da Silva L. Occupational exposure to pesticides and thyroid function in Brazilian soybean farmers. Chemosphere (2019) 218:425-29. doi: 10.1016/ j.chemosphere.2018.11.124

101. Docimo G, Cangiano A, Romano RM, Pignatelli MF, Offi C, Paglionico VA, et al. The Human Microbiota in Endocrinology: Implications for Pathophysiology, Treatment, and Prognosis in Thyroid Diseases. Front Endocrinol (Lausanne) (2020) 11:586529. doi: 10.3389/fendo.2020.586529

102. Virili C, Fallahi P, Antonelli A, Benvenga S, Centanni M. Gut microbiota and Hashimoto's thyroiditis. Rev Endocr Metab Disord (2018) 19:293-300. doi: $10.1007 / \mathrm{s} 11154-018-9467-\mathrm{y}$

103. Zhao F, Feng J, Li J, Zhao L, Liu Y, Chen H, et al. Alterations of the Gut Microbiota in Hashimoto's Thyroiditis Patients. Thyroid (2018) 28:175-86. doi: $10.1089 /$ thy.2017.0395

104. Cornejo-Pareja I, Ruiz-Limón P, Gómez-Pérez AM, Molina-Vega M, Moreno-Indias I, Tinahones FJ. Differential Microbial Pattern Description in Subjects with Autoimmune-Based Thyroid Diseases: A Pilot Study. J Pers Med (2020) 10:192. doi: 10.3390/jpm10040192

105. Zhang J, Zhang F, Zhao C, Xu Q, Liang C, Yang Y, et al. Dysbiosis of the gut microbiome is associated with thyroid cancer and thyroid nodules and correlated with clinical index of thyroid function. Endocrine (2019) 64:564-74. doi: 10.1007/s12020-018-1831-x

106. Aitbali Y, Ba-M'hamed S, Elhidar N, Nafis A, Soraa N, Bennis M. Glyphosate based- herbicide exposure affects gut microbiota, anxiety and depression-like behaviors in mice. Neurotoxicol Teratol (2018) 67:44-9. doi: 10.1016/ j.ntt.2018.04.002

107. Mao Q, Manservisi F, Panzacchi S, Mandrioli D, Menghetti I, Vornoli A, et al. The Ramazzini Institute 13-week pilot study on glyphosate and Roundup administered at human-equivalent dose to Sprague Dawley rats: effects on the microbiome. Environ Health (2018) 17:50. doi: 10.1186/s12940-018-0394-x

108. Lozano VL, Defarge N, Rocque LM, Mesnage R, Hennequin D, Cassier R, et al. Sex-dependent impact of Roundup on the rat gut microbiome. Toxicol Rep (2018) 5:96-107. doi: 10.1016/j.toxrep.2017.12.005

109. Dechartres J, Pawluski JL, Gueguen MM, Jablaoui A, Maguin E, Rhimi M, et al. Glyphosate and glyphosate-based herbicide exposure during the peripartum period affects maternal brain plasticity, maternal behaviour and microbiome. J Neuroendocrinol (2019) 31:e12731. doi: 10.1111/jne.12731

110. Tang Q, Tang J, Ren X, Li C. Glyphosate exposure induces inflammatory responses in the small intestine and alters gut microbial composition in rats. Environ Pollut (2020) 261:114129. doi: 10.1016/j.envpol.2020.114129

111. Mesnage R, Teixeira M, Mandrioli D, Falcioni L, Ducarmon QR, Zwittink RD, et al. Use of Shotgun Metagenomics and Metabolomics to Evaluate the Impact of Glyphosate or Roundup MON 52276 on the Gut Microbiota and Serum Metabolome of Sprague-Dawley Rats. Environ Health Perspect (2021) 129:17005. doi: 10.1289/EHP6990

112. Hu J, Lesseur C, Miao Y, Manservisi F, Panzacchi S, Mandrioli D, et al. Lowdose exposure of glyphosate-based herbicides disrupt the urine metabolome and its interaction with gut microbiota. Sci Rep (2021) 11:3265. doi: 10.1038/ s41598-021-82552-2

113. Motta EVS, Mak M, De Jong TK, Powell JE, O'Donnell A, Suhr KJ, et al. Oral or Topical Exposure to Glyphosate in Herbicide Formulation Impacts the Gut Microbiota and Survival Rates of Honey Bees. Appl Environ Microbiol (2020) 86:e01150-20. doi: 10.1128/AEM.01150-20 
114. Motta EVS, Moran NA. Impact of Glyphosate on the Honey Bee Gut Microbiota: Effects of Intensity, Duration, and Timing of Exposure. mSystems (2020) 5:e00268-20. doi: 10.1128/mSystems.00268-20

115. Ruuskanen S, Rainio MJ, Gómez-Gallego C, Selenius O, Salminen S, Collado $\mathrm{MC}$, et al. Glyphosate-based herbicides influence antioxidants, reproductive hormones and gut microbiome but not reproduction: A long-term experiment in an avian model. Environ Pollut (2020) 266:115108. doi: $10.1016 /$ j.envpol.2020.115108

116. Suppa A, Kvist J, Li X, Dhandapani V, Almulla H, Tian AY, et al. Roundup causes embryonic development failure and alters metabolic pathways and gut microbiota functionality in non-target species. Microbiome (2020) 8:170. doi: 10.1186/s40168-020-00943-5
Conflict of Interest: The authors declare that the research was conducted in the absence of any commercial or financial relationships that could be construed as a potential conflict of interest.

Copyright (๑) 2021 Romano, Oliveira, Oliveira, Oliveira, Torres, Bargi-Souza, Martino Andrade and Romano. This is an open-access article distributed under the terms of the Creative Commons Attribution License (CC BY). The use, distribution or reproduction in other forums is permitted, provided the original author(s) and the copyright owner(s) are credited and that the original publication in this journal is cited, in accordance with accepted academic practice. No use, distribution or reproduction is permitted which does not comply with these terms. 